Discourse and Communication for Sustainable Education, vol. 10, no. 2, pp. 33-48, 2019

\title{
Youth Start Social Entrepreneurship Program for Kids: Portuguese UKIDS-Case Study
}

\author{
Maria Inês Pinho, Dárida Fernandes, \\ Carla Serrão, and Daniela Mascarenhas \\ Politécnico do Porto, Porto, Portugal
}

\begin{abstract}
Today's society has valued entrepreneurship in various sectors of personal and professional life, but the school seems to forget this reality. Aware of this fact, the Portuguese Ministry of Education has created a program, from early childhood education to basic and secondary education, to develop the concept of social entrepreneurship in schools. The Porto Polytechnic Higher School of Education, as an educator of teachers and teachers of the First and Second cycle of Basic Education, joined the European UKIDS project to integrate this theme in the initial and continuous teacher training. In this article we will analyze the data obtained from a UKIDS Portuguese Partner School in the context of continuing teacher education and present some conclusions. The qualitative methodology used allowed us to conclude that the UKIDS project enhanced the valorization of individual capacities, such as creativity, self-confidence, the power of argumentation, as well as the construction of social competences, in interpersonal and group relationships, which are crucial in the formation of a child's personality in the basic school learning process.
\end{abstract}

Key words: entrepreneur, sustainable entrepreneurship education, entrepreneurial challenge-based learning, social entrepreneurship.

\section{Introduction}

The Youth Start Social Entrepreneurship Program for Kids was developed in six countries (Austria, Denmark, Finland, the Netherlands, Hungary and Portugal) and is cooperatively funded by the Erasmus+ program, measure KA2 (Cooperation for Innovation and the Exchange of Good Practices). The UKIDS framework aims to promote social entrepreneurship in education as a permanent element in the teaching-learning process, both in initial and continuing education of teachers. Regarding the objectives, the project aims to encourage the assumption of social responsibility, enhance the sense of social and civic belonging, among others. Strategies include the development of a social entrepreneurship program that promotes entrepreneurial skills and competences, from three specific groups: primary school children; future teachers (training programs and initial pedagogical practice); and teachers (through continuing education programs). 
The objective of this article is to analyse the results of UKIDS at Portuguese primary schools. In Portugal, the research on entrepreneurship was developed in a partner school of the UKIDS European project and in the initial teacher training of the School of Education of Polytechnic Porto, namely in the Supervised Teaching Practice of the Master's Teaching Course of $1^{\text {st }}$ Cycle of Basic Education (CEB) and in the Mathematics and Natural Sciences in the $2^{\text {nd }} C E B$. In this article we will present some results obtained in the partner school, with students from the $3^{\text {rd }}$ and $4^{\text {th }}$ grade.

\section{Entrepreneurship Education}

Entrepreneurship is the "ability of the individual to turn ideas into actions" not only for socioeconomic development but also for broadening their civic participation (EACEA, 2016, p. 5). The European Commission understands that entrepreneurship education is an essential aspect for the sustainable development of today's societies and, as such, a general and cross-cutting theme for citizens to develop (CCE, 2006; Council of the European Union, 2018; EACEA, 2016; Moreira, Alves, \& Silva, 2016). Following this European standard also, the Portuguese Government adopts this premise and proposes Entrepreneurship as one of the key competences for Portugal until 2020 (Alves, 2016; Moreira et al., 2016; Official Journal of the European Union, 2006).

Along these lines, Entrepreneurship Education in the school context develops in an environment that encourages active forms of learning and promotes lifelong citizen development. Thus, it aims to support the individual in the construction of knowledge, skills, attitudes and values (Wu \& Chen, 2019), based on observation, reflection and questioning about the realities, needs and interests of societies. To build the entrepreneurial profile, students need to know the different contexts and opportunities to transform ideas into action, for personal, social and professional activities and to understand how they arise. In this thinking, individuals should know and understand project planning and management approaches that include both processes and resources. They must understand the economy and the social and economic opportunities and challenges that an employer, organization or society faces. Along with this, they must also be aware of the ethical principles and challenges of sustainable development and be aware of their own strengths and weaknesses. In other words, they should have an entrepreneurial attitude, incorporate entrepreneurship, develop a social entrepreneurship concept (like this, they should be social entrepreneurs) and look for sustainable goals.

An Entrepreneurial Attitude is then characterized by a sense of initiative and management, proactivity, courage and perseverance to achieve goals, being focused on the future. It understands the desire to motivate others and to value their ideas, to build empathy, to care for people and the world, and to accept the responsibility of following ethical beliefs throughout the process.

It should be noted that entrepreneurship education has different social effects, both in the short and long term. In the short term, the intended results focus substantially on raising awareness of the topic, gaining theoretical and practical knowledge about entrepreneurship and the business world, developing entrepreneurship and entrepreneurial skills and attitudes, developing competences for self-confidence, empathy, the acquisition of entrepreneurial values and beliefs, and the motivation or inspiration for business creation. According to the guidelines of the European Commission, it is therefore up to the educational institutions to Incorporate Entrepreneurship, either transversely (across 
a curriculum and developed by various subjects), or from specific subjects (CCE, 2006, p. 9). Mendes (2019) also adds the need to articulate a model of entrepreneurship skills in the context of school and vocational guidance, with a structured curriculum of management training. The first dimension should enhance professional, personal and interpersonal skills and provide information according to the areas of interest of each person, and the second should enable the acquisition of specific skills, which are fundamental for analysing market functioning, individual and associative initiatives of business creation (Mendes, 2019).

Another noteworthy concept is that of Social Entrepreneurship, because, contrary to the notion of entrepreneurship, it evokes ideas and actions that aim to solve social problems and, thus, is not directed to markets, but to communities in situations of vulnerability or social risk. In this sense, social entrepreneurship is a non-profit initiative seeking alternative financing strategies or management systems to create social value (Austin, Stevenson, \& Wei-Skillern, 2006); a social obligation on the part of companies engaged in intersectoral partnerships (Sagawa \& Segal, 2000); or a means to alleviate social problems and catalyse social transformations (Seelos \& Mair, 2005). The Social Entrepreneur is, in this order of ideas, a social agent who, through innovation and existing resources, seeks solutions to social problems, aiming at social, economic and community development (Vieira \& Gauthier, 2000).

In addition, promoting entrepreneurship education requires global thinking and local action, and all efforts must therefore be combined to meet the Sustainable Development Goals (United Nations General Assembly, 2015). This agreement provides for the achievement of 17 goals - but 169 goals by 2030 . The goals and targets will stimulate action for the next 15 years in areas of crucial importance to humanity such as the PEOPLE (namely, ending poverty and hunger in all areas, forms and dimensions, for ensuring that all human beings can realize their potential in dignity and equality in a healthy environment, PLANET (respectively, protecting the planet from degradation, especially through sustainable consumption and production, sustainable management of its natural resources and taking urgent action on climate change to meet the needs of present and future generations, PROSPERITY (above all, ensuring that all human beings can enjoy a prosperous and fulfilling life of economic, social and technological progress in harmony with nature), PEACE (especially promoting peaceful fair and inclusive cultures that are free from fear and violence) and PARTNERSHIP (mainly with a spirit of global solidarity focused on the needs of the poorest and most vulnerable of people, and with the participation of all countries, all stakeholders and of all people). In short, the sustainable development of a country is the result of the sustainable development of all parts (regions, states, municipalities and neighbourhoods) that compose it. Thus, the concept of local development is introduced, in which entrepreneurship makes use of local characteristics, vocations and appeals, in the most diverse categories, which have, to some extent, a certain degree of autonomy from one another (economic, social, cultural, environmental, physical-territorial, political-institutional and scientific-technological) (Tenório, 2004).

From another perspective, Suleimenova and Ivanova (2018) refer to the concept of Sustainable Development as referring to the relationship between nature and society. For these authors this concept is subdivided into:

- Sustainable Social Development or related to equality of the Person or social justice, 
- Sustainable Economic Development or the maintenance of material, human or cultural capital or

- Sustainable Ecological Development or related to the well-being of people provided by the maintenance of raw materials and the environment (Fedosejeva et al., 2018; Salīe, 2015).

This last point is further supported by Kerscher (2019) when referring to the concepts of Circular Economy and Sustainability Education.

From another perspective, Manigova and Bogueva (2019), Machingura et al. (2018) and Newman (2018) refer to the need to create systems that collaborate for education in the objectives of sustainable development. For these authors, the most urgent objectives are climate change, the eradication of poverty and making the entire world population inclusive in achieving these goals.

Based on these assumptions, the Youth Start Social Entrepreneurship Program for Kids was developed, and TRASH VALUE activity was chosen as a way to prepare children, their families and school stakeholders for the new global challenges.

\section{Methodology}

The methodology used was of a qualitative nature, trying to understand the degree of evolution of the acquisition and mobilization of various competences, namely:

a) the concept that each child has, about a person being entrepreneurial,

b) the impact of the conception of entrepreneurship in each child namely: creativity, awareness of respect for the environment, knowledge sharing, the ability to communicate their ideas and be convincing, and more,

c) the opportunities and difficulties of the UKIDS project felt by each child, and

d) the skills reordered late to the development of reasoning and the capacity to learn more mathematics.

It was necessary to construct a questionnaire which was organized according to those ideas; these served as a pre-test and a post-test to study the evolution of each child and each class about the social skills associated with this theme. To validate this data collection instrument, the questionnaire was also piloted. This was semi-structured, with open, closed and semi-closed questions and in these last questions with four levels of classification, with questions of a logical trivalent nature (Yes, No and Maybe) and with the request for justification of the answer, when it was necessary.

The pre-test and post-test were applied in two contexts, because they were very similar as we can see in the characterization of context, respectively, in the second week of January and the last week of June.

On the other hand, in order to perform data triangulation and its application, in a convergent and credible look of the investigation, other data collection instruments were also used, specifically: participant observation, logbooks, informal conversations with children and field notes written by the class teachers and the researcher.

Based on the challenges proposed in the UKIDS, $3^{\text {rd }}$ and $4^{\text {th }}$ grade teachers outlined a planning, a programming of the intervention of the challenges throughout the school year and the integration in different areas of the existing curriculum in Portugal, such as show in the following Figure 1 and Figure 2. 


\begin{tabular}{|c|c|c|}
\hline Age group & Ukids Programme & Operation schedule \\
\hline \multirow{4}{*}{$3^{\text {rd }}$ grade } & $\begin{array}{l}\text { Idea challenge } \\
\text { (get your ideas moving forward) }\end{array}$ & November 4 periods \\
\hline & Lemonade stand challenge Market Day & \\
\hline & Be a yes challenge & All year / 15 periods \\
\hline & Trash value challenge & January / 6 periods \\
\hline \multirow{4}{*}{$4^{\text {th }}$ grade } & Idea challenge (create value) & \\
\hline & $\begin{array}{l}\text { Emphathy challenge (my feelings - } \\
\text { your feelings: Giraffe Language) }\end{array}$ & All year / 10 periods \\
\hline & Storytelling challenge & January / 4 periods \\
\hline & Community challenge & \\
\hline
\end{tabular}

Figure 1. UKIDS program for the $3^{\text {rd }}$ and $4^{\text {th }}$ grade with materials for students and teachers at the primary schools

\begin{tabular}{|l|l|l|l|}
\hline \multicolumn{1}{|c|}{ Challenges } & \multicolumn{1}{|c|}{ Subjects } & \multicolumn{1}{c|}{ Curriculum Contents } & \multicolumn{1}{c|}{ Social Development Goal } \\
\hline $\begin{array}{l}\text { Idea challenge } \\
\text { (get your ideas moving } \\
\text { forward) }\end{array}$ & $\begin{array}{l}\text { - Language } \\
\text { - Social studies } \\
\text { - Math }\end{array}$ & $\begin{array}{l}\text { - Reading/Comprehension } \\
\text { - Local economic activities } \\
\bullet \text { Money }\end{array}$ & $\begin{array}{l}\text { Responsible consumption } \\
\text { and production }\end{array}$ \\
\hline $\begin{array}{l}\text { Lemonade stand } \\
\text { challenge Market Day }\end{array}$ & & & \\
\hline Be a yes challenge & - Social studies & - Mind and body well-being & Good health well-being \\
\hline Trash value challenge & $\begin{array}{l}\text { - Language } \\
\text { - Social Studies }\end{array}$ & $\begin{array}{l}\text { - Reading and writing } \\
\text { - Environment }\end{array}$ & $\begin{array}{l}\text { Green cities and } \\
\text { communities }\end{array}$ \\
\hline $\begin{array}{l}\text { Idea challenge } \\
\text { (create value) }\end{array}$ & $\begin{array}{l}\text { - Language } \\
\text { - Social Studies } \\
\text { - Math }\end{array}$ & $\begin{array}{l}\text { - Oral speech } \\
- \text { National economic activities } \\
\text { - Money }\end{array}$ & $\begin{array}{l}\text { Honest work and economic } \\
\text { growth }\end{array}$ \\
\hline $\begin{array}{l}\text { Emphathy challenge } \\
\text { (my feelings - your feelings: } \\
\text { Giraffe Language) }\end{array}$ & $\begin{array}{l}\text { - Language } \\
\text { - Drama }\end{array}$ & $\begin{array}{l}\text { - Oral speech } \\
\bullet \text { Role Play }\end{array}$ & $\begin{array}{l}\text { Peace, justice and strong } \\
\text { institutions }\end{array}$ \\
\hline Storytelling challenge & $\bullet$ Language & $\bullet$ Creative writing & No poverty \\
\hline Community challenge & & & \\
\hline
\end{tabular}

Figure 2. 9UKIDS program at the Partner Primary School: $3^{\text {rd }}$ and $4^{\text {th }}$ grade

It should also be noted that from the first moment there was a lot of dialogue, sharing and cooperation between the teachers. Thus, as the educational contexts were very similar, the same questionnaire was applied to both classes, as well as some of the challenges, with some differences according to the objectives set for the $3^{\text {rd }}$ and $4^{\text {th }}$ years of schooling of the Basic Education scheme for Portugal.

\section{The Context of the Study}

The children of the $3^{\text {rd }}$ grade was born in 2010 and are between 8 and 9 years old. In this sample, there are 12 boys and 12 girls, of a total of 24 pupils. Parents' ages were divided in 6 classes of interval, starting in 31-35 and finishing in 61-65 being observed that the oldest parents vary between 36-40 years old and correspond to 11 students. On the other hand, the ages of the mothers are in three classes, between the ages of 31- 
35, 36-40 and 41-45 years, being equally distributed, respectively, with 9, 6 and 9 mothers with these ages.

The $3^{\text {rd }}$ year parent's (fathers and/or mothers) have very diverse professions, but most have a high academic level (mostly, undergraduate degree). The most frequently observed ( $8 \%$ each) belong to the group of professions: lawyers, traders, researchers and teachers.

In the School's $4^{\text {th }}$ year Class, the children were born in 2009 and are between 9 and 10 years old. The distribution of the number of boys and girls is fair, in a total of 24 pupils. Parent's ages were divided in 8 classes of interval, starting in 25-30 and finishing in 51-60, being observed that the oldest parents vary between 36-40 years old and correspond to 9 students. On the other hand, the mothers' ages are divided in seven classes between 25-30 and 46-50. The age class with the greatest number of mothers is the 36-40 (with 9 mothers), followed by the class of 31-36 with 6 mothers. Also, the parents of the $4^{\text {th }}$ year class have very diverse professions from veterinary, teacher, architect, psychologist, manager, specialized technicians, hairdresser, model, factory employee, among others and almost all possess undergraduate level of studies.

In addition to this personal and family characterization, it should also be noted that in both classes the children show very similar attitudes, with high motivation for learning, with initiative, very curious and questioning, being very enthusiastic when they develop new activities in the School.

\section{Analysis and Discussion of Results}

Based on the data collection, the instruments indicated, and considering how the questions in the questionnaire were developed, the following analysis and discussion of results emerged. It should be noted that there was a previous concern with the motivation to promote the participation of the target public in the answers to the research methods. On the questionnaire was written a motivational introductory text mentioning that: "UKIDS is a project on entrepreneurship in education. You will actively participate in this project by planning, solving challenges and evaluating. YOU will record your opinion at various times: before starting the project, during and after solving the challenges". In the first open question: "What is an entrepreneurial person to you?" the answers of children were quite free and different, and their analysis was carried out in three fundamental categories: Know How to Learn, Know How to Do and Know how to be and "other”, which included imperceptible answers or non-answers (Table 1).

Table 1

What is an Entrepreneurial Person to You?

\begin{tabular}{ccc}
\hline Variable Categories & Frequency & Percentage \\
\hline Know how to learn & 26 & $54 \%$ \\
\hline Know how to do & 6 & $12 \%$ \\
\hline Know how to be & 9 & $19 \%$ \\
\hline Others & 7 & $15 \%$ \\
\hline Total & 48 & $100 \%$ \\
\hline
\end{tabular}

As it can be observed, the biggest number of answers preferred the idea that the children thought to learn more with the project (26 in 48 answers or $54 \%$ of the answers). 
However, in the post-test and after the development of the tasks scheduled for the period January to June, two new categories were included, as the following chart shows, namely "one person having many ideas", in their various aspects, whether they were implemented or not and "never give up on goals" or "to achieve the aims" shown in Figure 3.

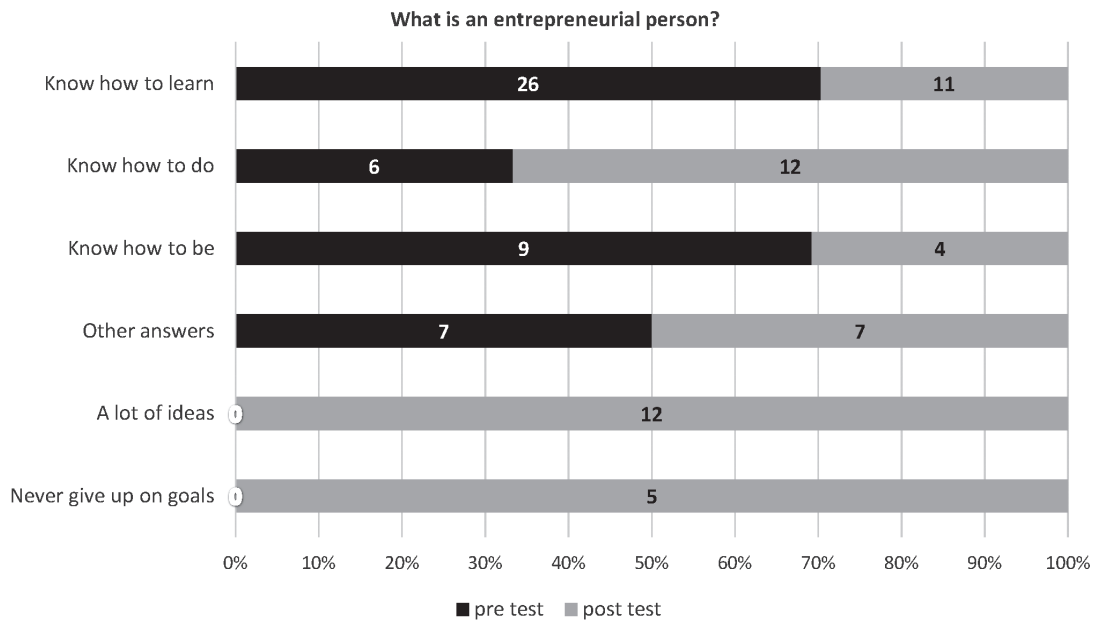

Figure 3. Children's ideas about entrepreneurship concept

In the first question, it was noted that children allied entrepreneurship with a person who enjoyed learning by writing: "He is a person who likes to learn"; "an enterprising person wants to learn more" and "Knowing more"; or "It's a person who understood the things they did well." In the post-test the children wrote that an entrepreneurial person is: "a person with many ideas"; or "is a person who has many ideas and then realizes the ideas" ( 2 students who wrote this) or "is a person who has ideas and finds new things through them" or in the same line of thinking and more in the $4^{\text {th }}$ year: "a practical and thinking person" or "a person who has ideas and makes them" (2)"; "means that you are a person who has ideas and makes use of those ideas"; "You are a person who builds things with your ideas," as the following figure shows (Figure 4).

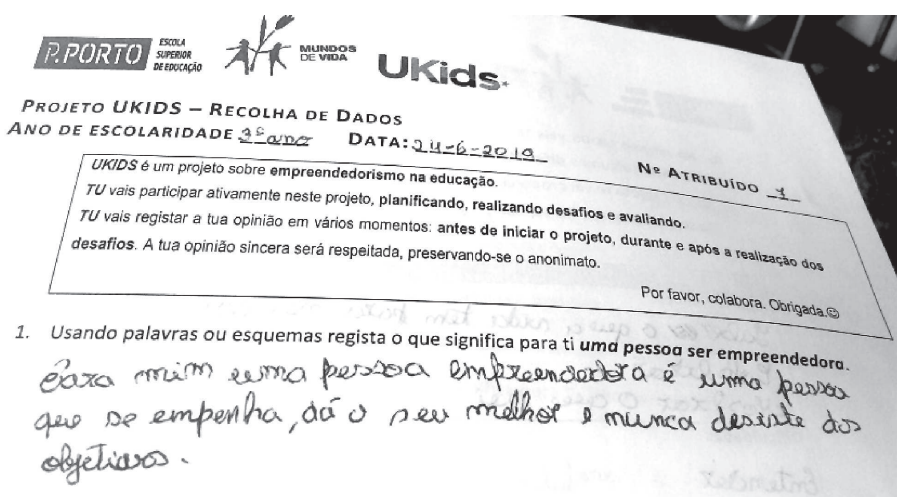

Figure 4. Example of answer given by child in post-test 
In the category of Know How To Be children answer "is a person who understands others," "is an entrepreneurial person". In this line of thought it is curious to note that one child connects entrepreneurial being with work and in the second semi-open question of the competence development writes "worker" competence, valorising the Know How to Do.

In Know How To Be, there were students who refer to an entrepreneurial person who shows other values, such as: "I think an entrepreneur means being a fair person," "For me an enterprising person is a good person," "Gives employment to others," "Likes others." It is interesting to note how the Know How To Do component increases in the post-test, but the Know How to Be component was decreased in the post-test, probably because in solving the challenges, children were encouraged to come up with ideas, reveal goals and risk achieving them individually or in a group.

Also, in the following scheme, one child includes the three categories, related to work to be entrepreneurial, to an understanding of learning and that at work is concerned with others and the results, as shown in the following figure (Figure 5).

1. Usando palavras ou esquemas regista o que significa para ti uma pessoa ser empreendedora.

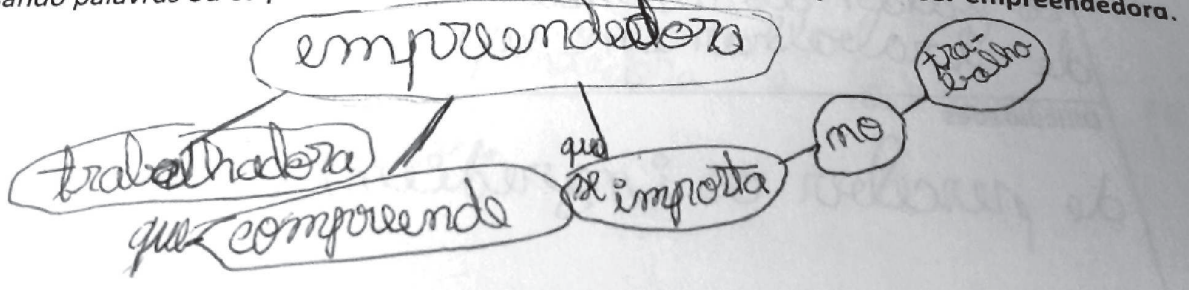

Figure 5. Competences to be an entrepreneurial person

We can conclude that for children, an entrepreneurial person is someone who is capable of learning, understanding (the process and the people), having ideas and realizing them. Everything indicates that the trilogy of Know How to Learn, Know How to Do and Know How to Be is present in the idea about entrepreneurship.

Regarding question 2, related to "the skills (abilities to do things) that the child hopes to develop in the UKIDS project on entrepreneurship...", the survey listed the following: awareness of social, environmental and political reality; creativity, self-confidence, autonomy, persistence, argumentation, curiosity; cooperation, respect, responsibility; and any other element to be indicated by the children. They have selected each element at one of the four levels, from 1 to 4, namely, I will not develop; I will develop little; I will develop and I will develop a lot.

The following chart (Figure 6) show the options marked by the children on the pretest and on the four levels. It should also be noted that the post-test results were also very positive, and the hope is with UKIDS children will develop a lot of creativity, curiosity, cooperation, respect and responsibility.

From the results obtained, it can be concluded that there is consistency with the first question of the questionnaire, because in this the children selected the skills they hope to develop in the UKIDS, such as creativity, that is, having ideas, curiosity, related to knowledge with more cooperation in sharing and communicating among your coworkers, respect for others and the choices made. 


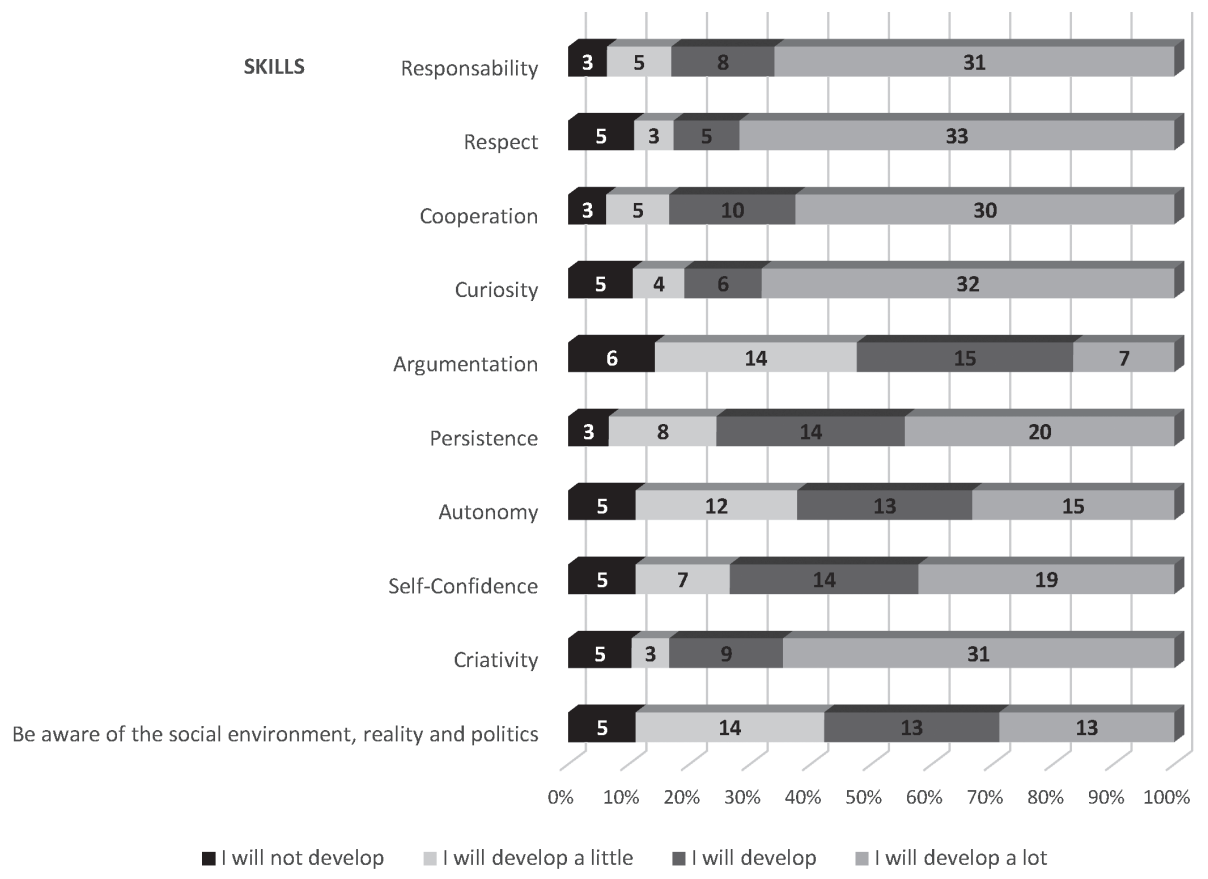

Figure 6. Competences that children hope to develop in UKIDS

In the analysis of some of the competences we will focus on some of them, such as self-confidence, argumentation, respect and responsibility, revealing the evolution obtained in the post-test. Thus, it is noteworthy that if in the pre-test 19 students wrote to develop a lot of self-confidence, in the post-test 30 students opted for this competence, an evolution of $23 \%$, as shown in the following graphs (Figure 7 ).
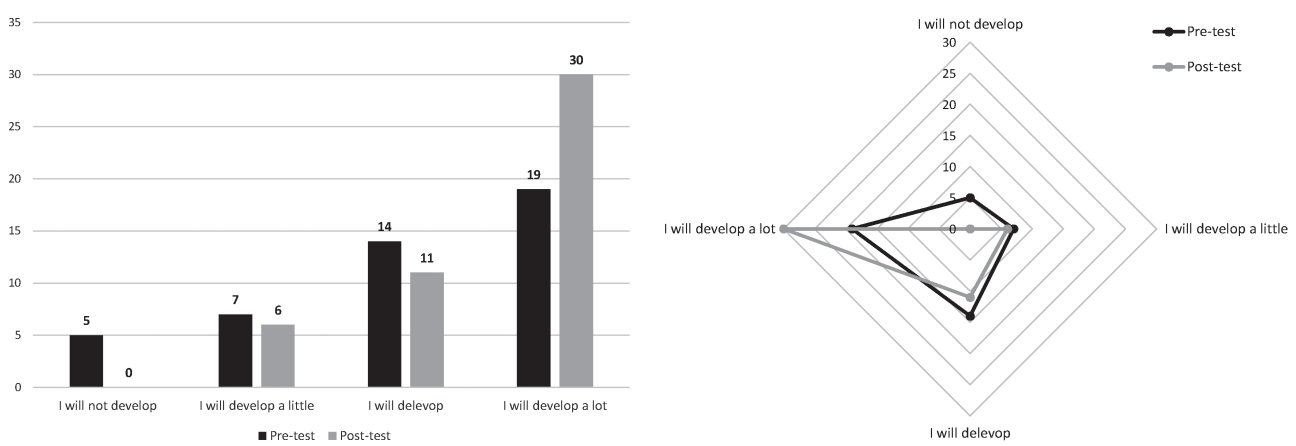

Figure 7. Social competence - self-confidence

This competence is very important for a child, as having self-confidence means reinforcing an intrinsic motivation for learning (Freire, 1996). In this way the child can build his/her identity by structuring ideas and putting them into practice. Another competence that changed in the post-test, in a positive way was the power of argumentation. The following chart (Figure 8) shows that the children expected to develop more the power of argumentation with the project (from 10 to 20 or double) and from 7 to 10 
expect to develop much with the resolution of the challenges. This skill is considered very difficult to achieve as it is usually related to reasoning and the ability to communicate with others using their own vocabulary and explaining their ideas clearly and consistently.

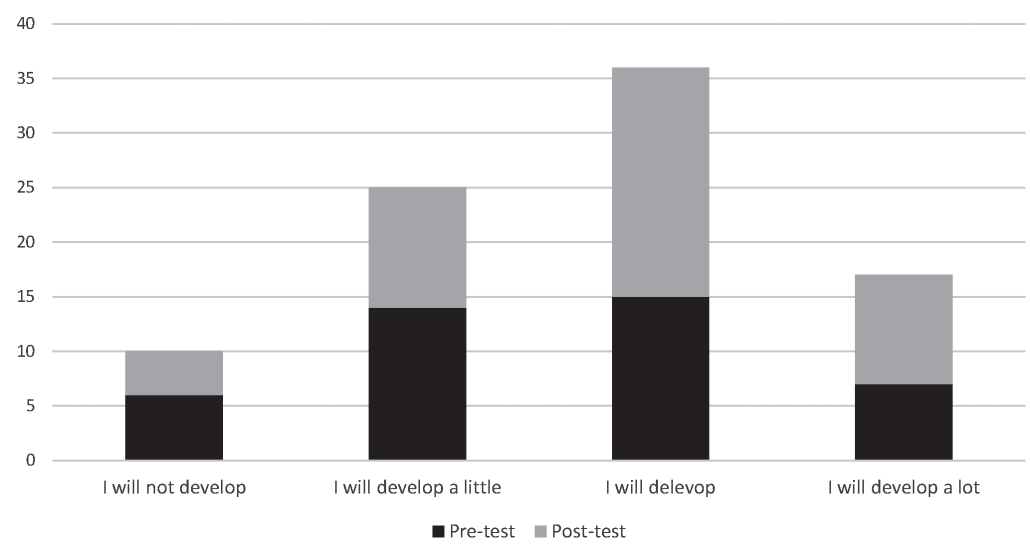

Figure 8. Social competence - argumentation

The following graph (Figure 9) compiles the competences of respect and responsibility and the results obtained in the pre-test and post-test. We can conclude then that both competences had a positive evolution of the competences and the children hoped to develop them very much in this project. It is interesting to associate these two competences with Know How to Be and Know How to Do (including of course Know How to Learn), with the acceptance of the added responsibilities when designing a project, respecting it in its conception and application, being always responsible in the different phases of development.

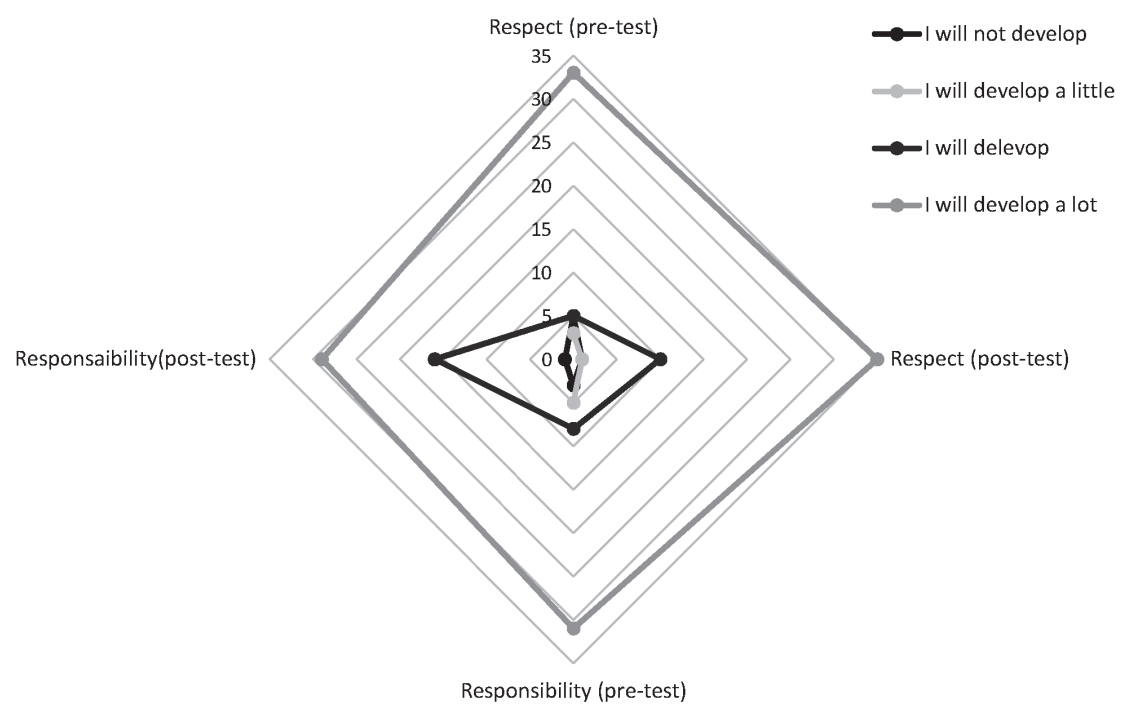

Figure. 9. Social competences of respect and responsibility 
In the third question of the questionnaire, we tried to perform a brief "SWOT analysis," considering only two parameters: the opportunities to be developed by the UKIDS project and the threats that may arise. Regarding the opportunities, the following chart highlights those indicated by the children (Figure 10).

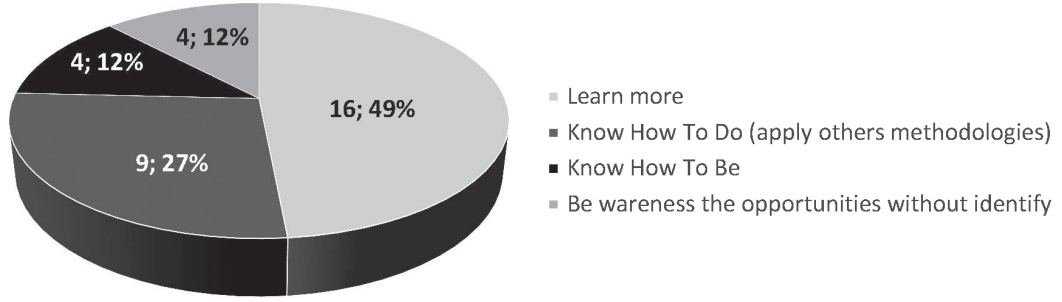

Figure 10. Opportunities of project UKIDS

As in other responses, children wrote about learning more $(49 \%$ - nearly half of children wrote it!), As well as the ability to Know How To Do, identified with the opportunity to solve challenges, to accomplish in group the tasks, concretize the proposals, trying new approaches (new methodologies), be able to ask the colleagues, be helped by them and collaborate in the accomplishment of the activities related to Know How To $B e$.

On the other hand, in the last open question: If you wish, you can still write more ideas about the Project or ask your questions, although nine of the children did not answer, almost half of those $(42 \%)$ showed a lot of curiosity about the project, as shown in the following graph (Figure 11). In addition, they expect to learn a lot from the UKIDS Project.

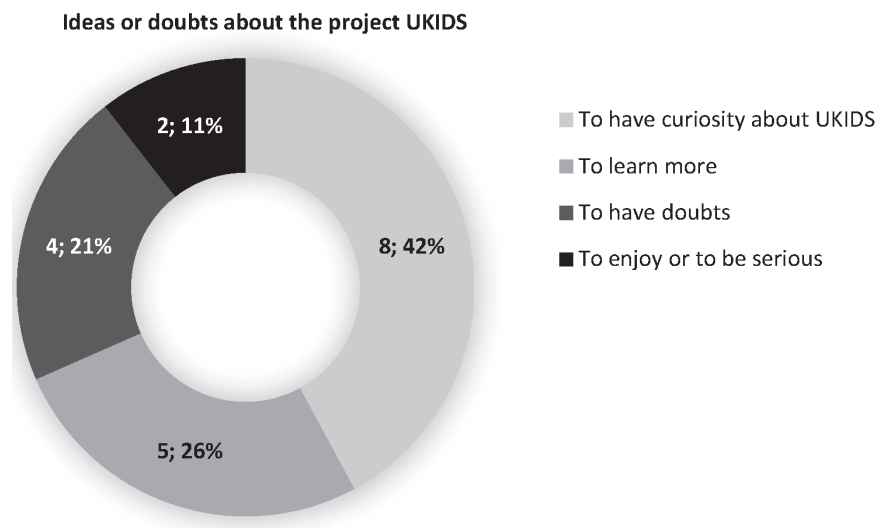

Figure 11. Open answers about UKIDS

We can conclude, observing the figure 11, that the children also revealed responsibility for belonging to the project, expressing fears and doubts about what they would accomplish at UKIDS. They believed that it would give them taste and fun, but at the same time they considered it very serious, something of great responsibility. In the question about the difficulties they may feel in the project, only 36 answered and some students (16) had "difficulties without identifying them." Nevertheless, two difficulties 
were identified: autonomy and self-confidence in the post-test, and skills related to the capacity to understand and solve problems. To complete this analysis, the following chart shows some of the difficulties listed by the children in the pre-test and post-test. In fact, Freire (1996) defends also that autonomy and self-confidence are important to achieve the ability of initiative and cooperate with others, developing the social competences.

On the other hand, they wrote the following difficulties, as show Figure 12.

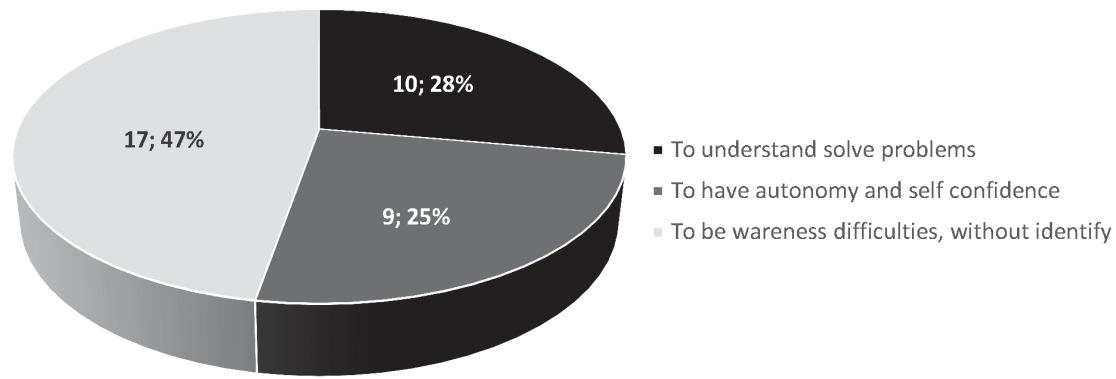

Figure 12. Difficulties that children can have in the UKIDS

Most of the children answered this question, to be aware of the project's identity, some of the difficulties, like the ability to understand and solve problems, or showing coherence when they admit that the project will help them to know more Mathematics (see in the analysis of the next question), and this discipline is closely linked to reasoning and problem solving. They also lacked confidence in their abilities and their autonomy in solving the challenges ahead. As Mathematics is a discipline in which children show some difficulties, we link the project to this scientific area. In the following graph (Figure 13) the children believed that being in the project would develop their reasoning further.

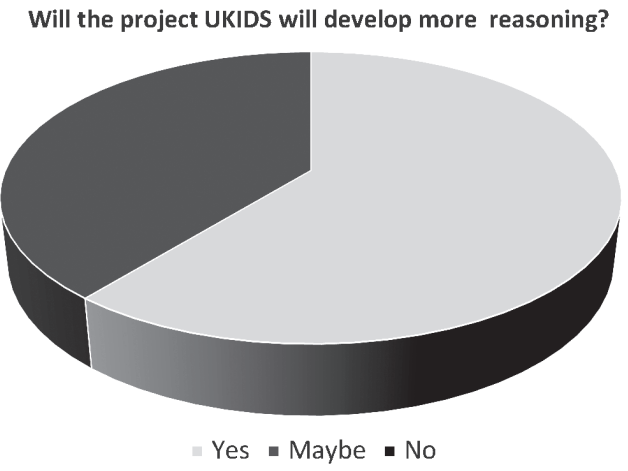

Figure 13. Developing reasoning

Note that no child answered "No", that is, of the 46 children who answered this item and believed that the project could enhance the development of reasoning. More than $50 \%$ of children say "Yes." Identical values were recorded in the post-test. On the other hand, they were confident that UKIDS would help them learn more Math $(67 \%$ Yes and 27\% Maybe), as show Figure 14. 
The project UKIDS will help you to learn more Mathematics?

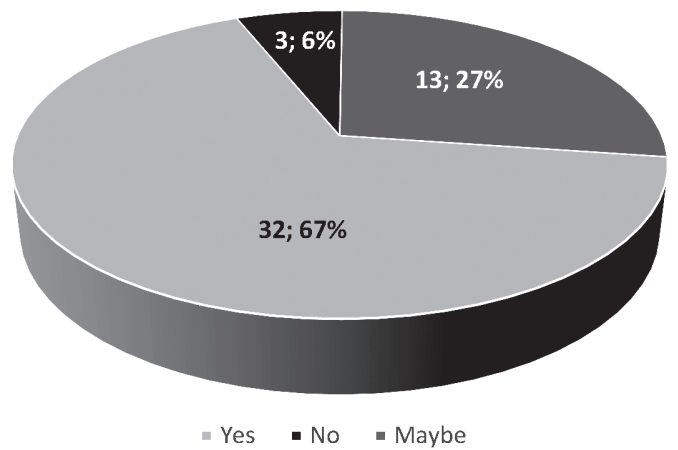

Figure 14. Learning more mathematics

Interestingly, the answers to these two items revealed that children related the UKIDS project to the development of reasoning and the ability to learn, and learn more different subjects, specially Maths.

\section{Some Reflections and Conclusions}

Entrepreneurship is not only "to shape the mindsets of young people, but also to equip them with the skills, knowledge and attitudes that are indispensable for the development of the entrepreneurial culture" (European Commission/EACEA/Eurydice, 2016, p. 9). In fact, the UKIDS project is an excellent opportunity for the integral development of the person, from a European and participatory perspective, where each country has its idiosyncrasies - but allowing, as can be seen in scheme 1, the integration of multiculturality of essentialities: capacities, and knowledge; Skills; attitudes and values (Figure 15), in a social culture, respectively, marked by Know How to Learn, Know How to Do and Know How To Be.

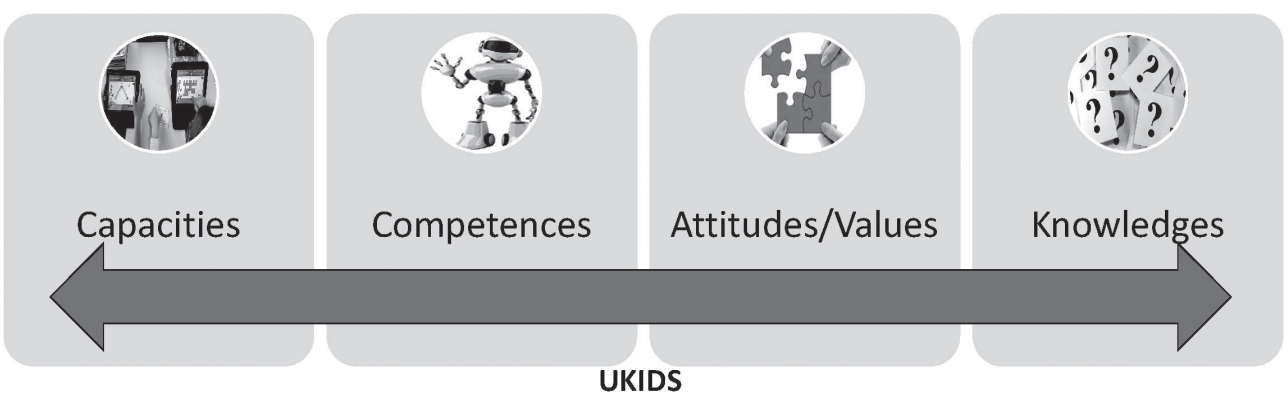

Figure 15. Social culture seen in an interdisciplinary way

The development of these competences was always present not only in the diagnostic phase and in the initial presentation of the project, but also in its development and in the resolution of the challenges. In fact, children related entrepreneurship to knowing more, but also related it to knowledge understood as "a person who has a lot of ideas and understands things well." 
Recording the initial concept of entrepreneurship of $3^{\text {rd }}$ and $4^{\text {th }}$ grade children before applying the challenges of the UKIDS project was crucial to getting to know the initial and subjective idea and to understand the evolution in each child and in each class. In the concept of a person being entrepreneurial, it was noted that inclusion after the posttest application of the two new categories: showing evolution in the idea of entrepreneurship, becoming even more complete, children integrated the need for a person to have ideas and to realize them.

It is also important to record in the resolution of the challenges of UKIDS, the children related to Mathematics, hoping through the project to have more opportunities to develop reasoning, to learn more Mathematics and to solve better the problems associated with this subject.

From the data collated, it can be concluded that the children mobilized, in a deeper way, personal and social competences very relevant to the development of their personality, such as: respect for their colleagues, the tasks to be performed, the responsibility of knowing how to think and to do, and the motivation to learn more. Children also recognize that for a person to be entrepreneurial, they will need to have ideas, be creative and not give up on the goals set. In carrying out the tasks, they highly valued cooperation and their thinking, and associated UKIDS with mathematics, problem solving and the development of reasoning.

\section{Conclusions}

From the paper the authors have developed emerged different dimensions: the individual and/or team class knowledge and attitude; the social impact of environment in family, stakeholders; the new education of teacher's training in the initial and continuum process.

Conclusively, the students are motivated to learn and to work in these public causes and they are receptive to think about new concepts, like "when is a person being entrepreneurial?" and they believe that creativity, the respect for environment, the method of cooperation, and the communication about their ideas, all are important to construct new sustainable development.

In fact, the project UKIDS is an opportunity to learn more about the world and to discover a new sustainable development. They feel that only together can they learn more and change the world in a preferred way. They also believe that when they solve the challenges, they deepen their reasoning and new mathematics skills - and this subject is also important in the physics, chemistry and other Scientifics areas.

On the other hand, with the use of UKIDS, we reflect in a European perspective and in a collaborative way so that we can discuss the objectives of sustainable development for education. In these collaborative works, it is urgent to define objectives about climate change, the eradication of poverty and making the entire world population inclusive in achieving these goals.

Based on these assumptions, the Youth Start Social Entrepreneurship Program for Kids (Ukids) has provided a social context to prepare children, their families and school stakeholders for the new global challenges. In this process, we conclude that it is necessary to dialogue and at the same time to discuss the agenda for the sustainable goals of the planet. 


\section{References}

Alves, V. P. T. (2016). Educação para o empreendedorismo: A ativação criativa no $1^{0}$ $C E B$ [Entrepreneurship Education: The creative activation in the Basic Education]. (Masters dissertation). Aveiro: Universidade de Aveiro.

Austin, J. E., Stevenson, H. H., \& Wei-Skillern, J. (2006). Social and commercial entrepreneurship: Same, different, or both? Entrepreneurship: Theory \& Practice, 30(1), $1-22$.

Council of the European Union, $8^{\text {th }}$ May 2018, Draft Council conclusions on moving towards a vision of an European education area (8701/18).

European Commission/EACEA/Eurydice. (2016). Entrepreneurship education at school in Europe. Eurydice report. Luxembourg: Publications Office of the European Union.

Fedosejeva, J., Boče, A., Romanova, M., Iliško, Dz., \& Ivanova, O. (2018). Education for sustainable development: The choice of pedagogical approaches and methods for the implementation of pedagogical tasks in the Anthropocene age. Journal of Teacher Education for Sustainability, 20(1), 157-179.

Freire, P. (1996). Pedagogia da Autonomia: saberes necessários à prática educativa [Autonomy Pedagogy: Knowledge necessary for educational practice]. São Paulo: Paz e Terra.

Machingura, F., Nyamwanza, A., Hulme, D., \& Stuart, E. (2018). Climate information services, integrated knowledge systems and the 2030 Agenda for Sustainable Development. Sustainable Earth, 1(5), 1-7.

Marinova, D., \& Bogueva, D. (2019). Planetary health and reduction in meat consumption. Sustainable Earth, 2(3), 1-12.

Mendes, A. R. O. (2019). Apontamentos sobre a educação para o empreendedorismo em Portugal [Notes on entrepreneurship education in Portugal]. Revista Portuguesa sobre pedagogia [Portuguese Journal on Pedagogy], 41(3), 285-298.

Moreira, N., Alves, M. P., \& Silva, A. M. C. (2016). A educação para o empreendedorismo em mediação: um estudo com estudantes universitários [Entrepreneurship education in mediation: A study with university students]. In A. M. C. Silva, M. L. Carvalho \& L. R. Oliveira (Eds.), Sustentabilidade da Mediação Social: processos e práticas [Social media sustainability: Processes and practices] (pp. 69_ 78). Braga: CECS.

Newman, P. (2018). Sustainable Earth begins its journey. Sustainable Earth, 1(2), 1-2. Official Journal of the European Union, 30 December 2006, Recommendation of the European Parliament and of the Council on key competences for lifelong learning (2006/962 / EC).

Sagawa, S., \& Segal, E. (2000). Common interest, common good: Creating value through business and social sector partnerships. California Management Review, 42(2), $105-122$.

Salite, I. (2015). Searching for sustainability in teacher education and educational research: Experiences from the Baltic and Black Sea Circle Consortium for educational research. Discourse and Communication for Sustainable Education, 6(1), 21-29.

Seelos, C., \& Mair, J. (2005). Entrepreneurs in service of the poor: Models for business contributions to sustainable development. Business Horizons, 48(3), 241-246.

Tenório, F. G. (2004). Responsabilidade Social Empresarial [Corporate Social Responsibility]. Brasil: FGV Editora. 
United Nations General Assembly. (2015). Transforming our world; the 2030 Agenda for sustainable development, A/RES/70/1.

Vieira, R., \& Gauthier, F. (2000). Introdução ao Empreendedorismo Social [Introduction to Social Entrepreneurship]. Anais. II Encontro Nacional do Empreendedor.

Wu, H. T., \& Chen, M. Y. (2019). Course design for college entrepreneurship education from personal trait analysis to operation in practice. Frontiers in Psychology, 10, 1016-1028.

Correspondence relating this paper should be addressed to Maria Inês Pinho, Escola Superior de Educação, Porto. Email: inespinho@ese.ipp.pt 